\title{
Production and Performance of Triploid Oysters for Aquaculture ${ }^{1}$
}

\author{
Huiping Yang, Natalie Simon, and Leslie Sturmer ${ }^{2}$
}

Consult the glossary at the end of this publication for explanations of italicized terms.

\section{Abstract}

Triploid oysters have become a major component of the oyster aquaculture industry worldwide. This review will focus on basic aspects of triploid oyster aquaculture, including the approaches for triploid induction, performance of triploids, and related ploidy determination. This review is intended to convey basic knowledge of triploid oyster aquaculture to the shellfish industry and general public.

\section{Introduction}

According to the Food and Agricultural Organization (FAO), molluscan shellfish aquaculture, including oysters, clams (including cockles and arks), mussels, scallops, and abalones, accounts for more than half of the world's marine aquaculture production (FAO 2016). Among the aquaculture shellfish groups, oysters led the annual production between 2003 and 2007, and since 2008 were second behind clams (Yang et al. 2016). Aquaculture information from the FAO lists over 15 oyster species from genera Ostrea and Crassostrea that are currently being farmed worldwide with a total production of more than 5 million tonnes and sales value exceeding $\$ 4$ billion (FAO 2016).
In the United States, oyster aquaculture includes five species: the Pacific oyster Crassostrea gigas, eastern oyster Crassostrea virginica (also previously known as the American oyster, a native species along the US East Coast and Gulf of Mexico), Kumamoto oyster Crassostrea sikamea, Olympia oyster Ostrea conchaphila (or O. lurida, a native species in the US West Coast), and European flat oyster Ostrea edulis. (See the National Aquaculture Association's poster, here: http://thenaa.net/pub/NAA-poster2.pdf). According to the most recent aquaculture census conducted by the U.S. Department of Agriculture (USDA) in 2012, 756 farms in 18 states are involved in the molluscan aquaculture industry with a sales value of $\$ 329$ million (USDA 2014). Among the cultured shellfish species, the Pacific oyster accounted for $26.4 \%$ of the production for an economic value of $\$ 87$ million on the west coast, while the eastern oyster accounted for $19.7 \%$ of the production for an economic value of $\$ 68$ million on the east and Gulf of Mexico coasts, and other oysters accounted for $7.6 \%$ of the total shellfish aquaculture production (USDA 2014).

Triploid-tetraploid technology is likely the genetic breeding most widely recognized by the oyster aquaculture industry worldwide and is utilized for commercial oyster seed production (Guo 2004). This publication reviews triploid oyster production and performance, and explains methods used to produce and raise triploid oysters.

1. This document is FA208, one of a series of the Fisheries and Aquatic Sciences Department, UF/IFAS Extension. Original publication date July 2018. Visit the EDIS website at http://edis.ifas.ufl.edu.

2. Huiping Yang, assistant professor, Program in Fisheries and Aquatic Sciences of the School of Forest Resources and Conservation; Natalie Simon, Ph.D. student, Program in Fisheries and Aquatic Sciences of the School of Forest Resources and Conservation; and Leslie N. Sturmer, UF/IFAS statewide shellfish Extension agent IV, Cedar Key, FL; UF/IFAS Extension, Gainesville, FL 32611.

The Institute of Food and Agricultural Sciences (IFAS) is an Equal Opportunity Institution authorized to provide research, educational information and other services only to individuals and institutions that function with non-discrimination with respect to race, creed, color, religion, age, disability, sex, sexual orientation, marital status, national origin, political opinions or affiliations. For more information on obtaining other UF/IFAS Extension publications, contact your county's UF/IFAS Extension office. 


\section{Triploid Oyster Aquaculture}

Like most animals, normal oysters have two sets of chromosomes (which means that they are diploid) with one set inherited from the eggs and the other inherited from the sperm. Triploid oysters have three sets of chromosomes and are valuable to the commercial aquaculture industry because of their potential for fast growth, superior meat quality (especially in summer), year-round harvestability, and low environmental pressure on wild populations (due to their sterility) (Guo et al. 2009). Tetraploid oysters possess four sets of chromosomes and are valuable in the production of $100 \%$ triploid seed when crossing with normal diploids.

Triploid oyster aquaculture has become an important part of the global industry. Currently, triploid Pacific oysters account for about $50 \%$ of the production on the west coast of the United States and 100\% of the hatchery seed production in France (Degremont et al. 2016). Triploid eastern oysters account for nearly $100 \%$ of the seed production in the Chesapeake Bay. Triploid Sydney rock oysters Saccostrea glomerata account for about $15 \%$ of the production in Australia (Peachey \& Allen 2016). Commercial triploid oysters are typically produced by crossing tetraploids with normal diploids to yield 100\% triploid seed. This approach allows for implementation by commercial hatchery operations and has supported oyster farming operations throughout the world.

\section{Methods for Triploid Oyster Production}

There are two approaches used for production of triploid oysters. The first approach is to inhibit the release of polar body I or polar body II after fertilization. This method has been used since 1981 when the first report of triploid production was published (Stanley et al. 1981). The second approach involves crossing normal diploids with tetraploids to produce $100 \%$ triploid offspring. This method is currently used in commercial triploid seed production but relies on the availability of tetraploid breeding stocks.

\section{1) Triploid Production by Inhibiting the Release of Polar Body I or II}

Oysters, especially Crassostrea species, reproduce by releasing their gametes (eggs from females and sperm from males) into the surrounding water for fertilization and embryo development. For many bivalve mollusks (oysters, clams, mussels, and scallops), eggs released from females are not completely mature (arrested in the prophase of meiosis I) (Galtsoff 1964; Gosling 2003). Once fertilization occurs, the eggs resume the maturation process (meiosis I and II) and release polar bodies I and II. The fertilized eggs develop into embryos and then free-swimming larvae after 24 hours. After about 2-3 weeks, swimming larvae go through metamorphosis and transform into sessile juveniles (spat), and continue to grow into adults.

Based on oyster reproductive characteristics, production of triploids can be achieved by inhibiting polar body I or polar body II, which alters the way chromosomes are inherited. This approach has been used to produce triploids in many shellfish species (see summary in Guo et al. 2009). Polar body I contains two sets of joined matching chromosomes and when inhibited can change the way chromosomes are separated, resulting in a mix of ploidies, including tetraploids, triploids, diploids, and aneuploids (organisms that do not possess whole sets of chromosomes) (Guo et al. 1992; Yang et al. 2000a). Often, only triploids and diploids survive to spat stage (Stanley et al. 1981; Yang et al. 2000b). Inhibition of polar body II usually produces a majority of triploids because the extra set of chromosomes in polar body II is kept. Therefore, inhibition of polar body II has been used as the effective approach for triploid production in shellfish (Allen et al. 1989; Guo et al. 2009).

Effective methods used to inhibit polar body I or II include: 1) physical treatments, such as high-pressure shock, heat shock, and cold shock; and 2) chemical treatments, such as cytochalasin $\mathrm{B}(\mathrm{CB}), 6$-dimethylamnpurine (6-DMAP), caffeine, colchicine, and nocodazole (see summary in Guo et al. 2009). For different shellfish species, the effective treatment conditions, such as concentration, duration, and starting time, are slightly different; details for the species studied so far were summarized in a review (Guo et al. 2009). For oysters, CB and 6-DMAP were the most commonly used methods for effective inhibition of polar bodies (Table 1).

Overall, inhibition of polar body I or II is an effective direct approach to produce triploids. Generally, the inhibition of polar body II produces higher percentages of triploids compared to the inhibition of polar body I, but no significant differences were identified when a systematic comparison was made using the same parents in hard clams (Yang \& Guo 2017).

Although inhibition of polar body I or II is an effective approach to produce triploids, this approach is not commonly used for commercial triploid seed production because: (1) $100 \%$ triploid offspring are rarely produced, and they vary greatly depending on gamete quality, egg development, 
treatment timeframe, duration, and water temperature; (2) triploid larval survival is lower than larval survival in control groups due to the treatment for polar body inhibition; and (3) chemicals used to inhibit polar bodies, such as cytochalasin B, may be a threat to human health.

To overcome the disadvantages of inhibiting polar body I or II for commercial triploid seed production, another method involving tetraploid oysters can be used. Tetraploid oysters offer a solution because they can be crossed with normal diploids to produce $100 \%$ triploids. A review of tetraploid oyster production will be covered in a follow-up publication.

\section{2) Triploid Production by Crossing Diploids with Tetraploids}

Theoretically, offspring from diploids $(2 \mathrm{~N})$ crossed with tetraploids $(4 \mathrm{~N})$ can produce $100 \%$ triploids (3N). Applications of this method are recognized in the successful establishment of tetraploid breeding stocks for several oyster species (Guo et al. 1994; Eudeline et al. 2000; Allen et al. 2005; Guo 2012). Currently, triploid seed production in most commercial hatcheries uses eggs from normal diploids that are fertilized with sperm from tetraploids. To ensure predictable spawning success and avoid contamination, gamete collection for triploid seed production is performed using the strip spawning method, which is applicable for most oyster species (but may not be for scallops, mussels, and clams).

The strip spawning procedure includes the following steps: open mature adult oysters (clean the knife between oysters to avoid contamination), determine the sex of each oyster by observing a smear of gonad under microscope $(40 \times$ magnification), keep females and males separate, strip gonad using a sharp scalpel, and rinse and suspend gametes into individual beakers with fresh seawater. Eggs may be collected on a $20-\mu \mathrm{m}$ screen by filtering through a $150-\mu \mathrm{m}$ screen to remove debris and may then be resuspended in fresh seawater. Sperm (from tetraploids) can be collected by filtering through a $15-\mu \mathrm{m}$ screen and resuspending in fresh seawater. Fertilization is performed by mixing eggs and sperm. Concentrations of $\sim 10-20$ sperm/egg are confirmed via microscopy (100-× magnification).

\section{Performance of Triploids over Diploids}

The intention of developing triploid oysters is to meet the industry's need for year-round marketable oysters, especially during the summer months when normal diploids are thin and watery after spawning. Typically, oysters spawn during the spring and fall. Before spawning, the stored energy is used for egg and sperm development within the gonad, which can occupy up to $50 \%$ of the soft tissue weight. After spawning, the oyster meat is considered unpalatable because tissue begins to soften and appears watery (Allen et al. 1989). Triploids are considered sterile with poor gonad development and are thought to redirect energy typically used for gonadal development to somatic growth, allowing them to increase in body size and maintain meat quality. Therefore, triploid oysters are well suited to meet the demands of the industry for a year-round marketable product.

The performance of triploids has been demonstrated at juvenile and adult stages in almost all of the studied shellfish species, most prominently in oysters and scallops after sexual maturation. An updated summary of the growth of triploid oysters at adult stage based on a review by Guo, X., Y. Wang, Z. Xu and H. Yang described in their article, "Chromosome set manipulation in shellfish" (Guo et al. 2009) is listed in Table 1.

\section{1) Fast Growth of Triploid Oysters}

At the larval stage, triploids and diploids did not show significant differences in survival (Guo et al. 2009). For larval growth, chemically induced triploids grew either faster than or about the same as diploids in the Pacific oysters (Downing \& Allen 1987). Superior growth was confirmed in triploid larvae produced from tetraploids in the Pacific oyster (Guo et al. 1996). Data collected from eyed larvae showed that triploid larvae had grown to 280-300 microns at settlement, while diploids had grown to 250-260 microns.

At the adult stage, superior growth of triploids has been confirmed in almost all oyster species studied. For the eastern oyster, triploids produced by inhibiting polar body I or II typically grew $12-41 \%$ faster than diploids (Table 1). Only one study displayed triploids with $0.7 \%$ smaller body size when compared to diploids (Wang et al. 2005). Impressively, triploids produced by diploids crossed with tetraploids $(2 \mathrm{n} \times 4 \mathrm{n})$ showed $192 \%$ faster growth than diploids (Table 1) and in some cases even higher due to selective breeding of tetraploid broodstock (based on a Rutgers University presentation at the National Shellfisheries Association's annual meeting in 2017). Commercially, triploid oysters cultured in Virginia can reach market size (over 3 inches, or $75 \mathrm{~mm}$ ) in 1.2 years, while diploids need 1.6 years (Harding 2007). In Florida, triploids take 10-14 months to reach market size from spawn while diploids 
need about 12-16 months (results of field trials conducted by Sturmer and growers during 2016-17, Sturmer et al. 2017) (Figure 1). For the Pacific oyster, chemically induced triploids showed $14-150 \%$ increased body size compared to diploid controls (Table 1), and triploids produced from tetraploids $(2 n \times 4 n)$ showed up to $159 \%$ faster growth than diploids (Table 1). For the other four oyster species, triploids produced from chemical inhibition of polar body I or II also showed a significant increase in body size (Table $1)$.

However, it is important to recognize that environmental factors (for example, food availability, temperature, and salinity) can also affect growth and survival of triploid oysters. In general, warm environments that are nutrientrich produce triploid oysters with substantially higher growth rates (Brake et al. 2004). Environments that are nutrient poor may explain the observations where triploid and diploid oyster growth are similar (Guo et al. 2009).

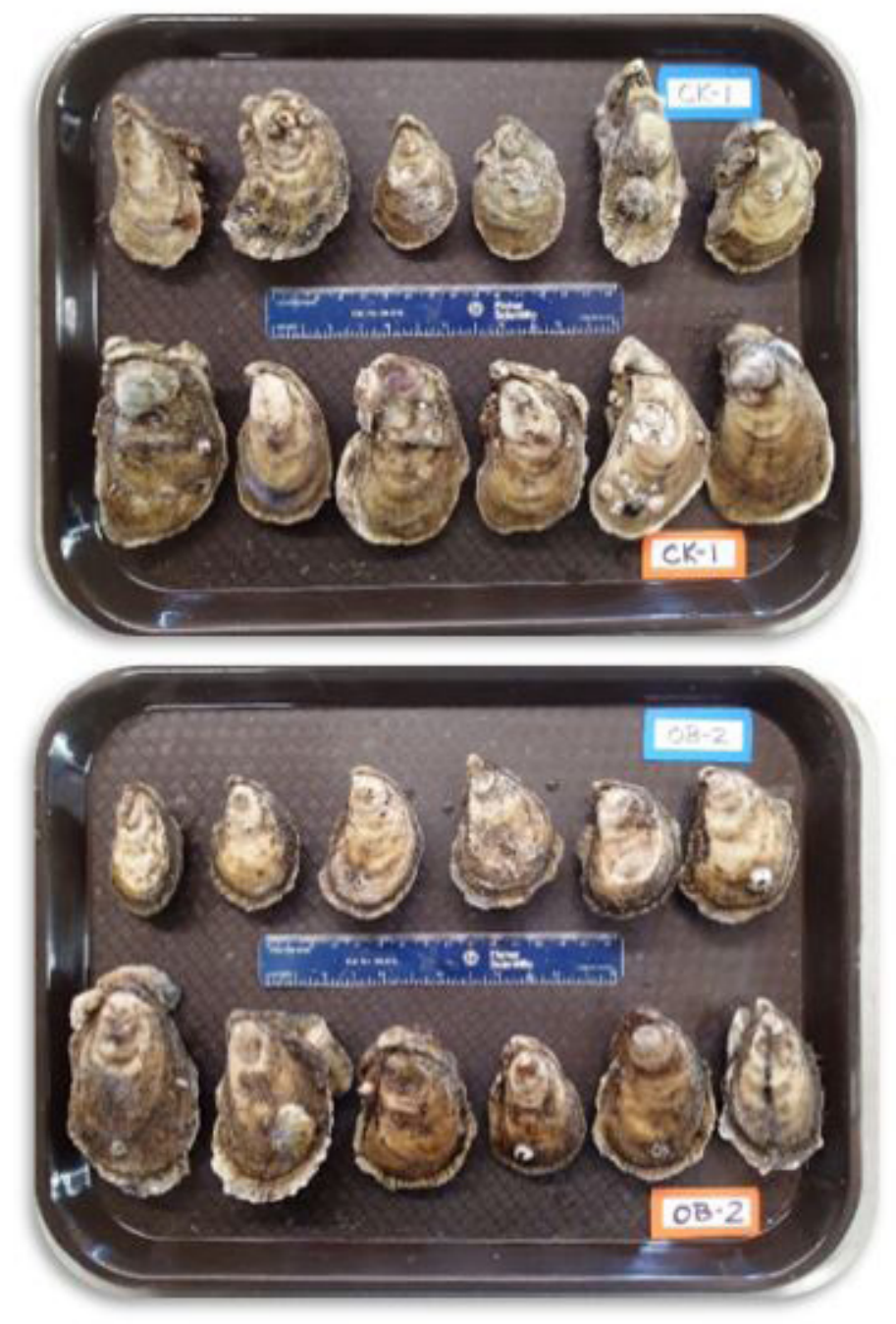

\section{2) Survival of Triploid Oysters}

Despite the benefits of summer meat conditions and higher growth rates, the triploid advantage in terms of survival varies across studies and environmental conditions. Recent experimental work has suggested that triploids appear to be more vulnerable to summer mortality (Wadsworth 2018). Triploid eastern oysters have experienced significantly higher mortalities than diploid oysters at sites along the Gulf of Mexico, and the results highlight the need for a better understanding of the triggers of summer mortality in triploids.

\section{3) Disease Resistance of Triploid Oysters}

The effects of triploidy on disease resistance have not been clearly established. Studies on susceptibility to dermo (caused by Perkinsus marinus) suggested that triploid and diploid eastern oysters reacted similarly and were equally susceptible to the disease (Barber \& Mann 1991). On the
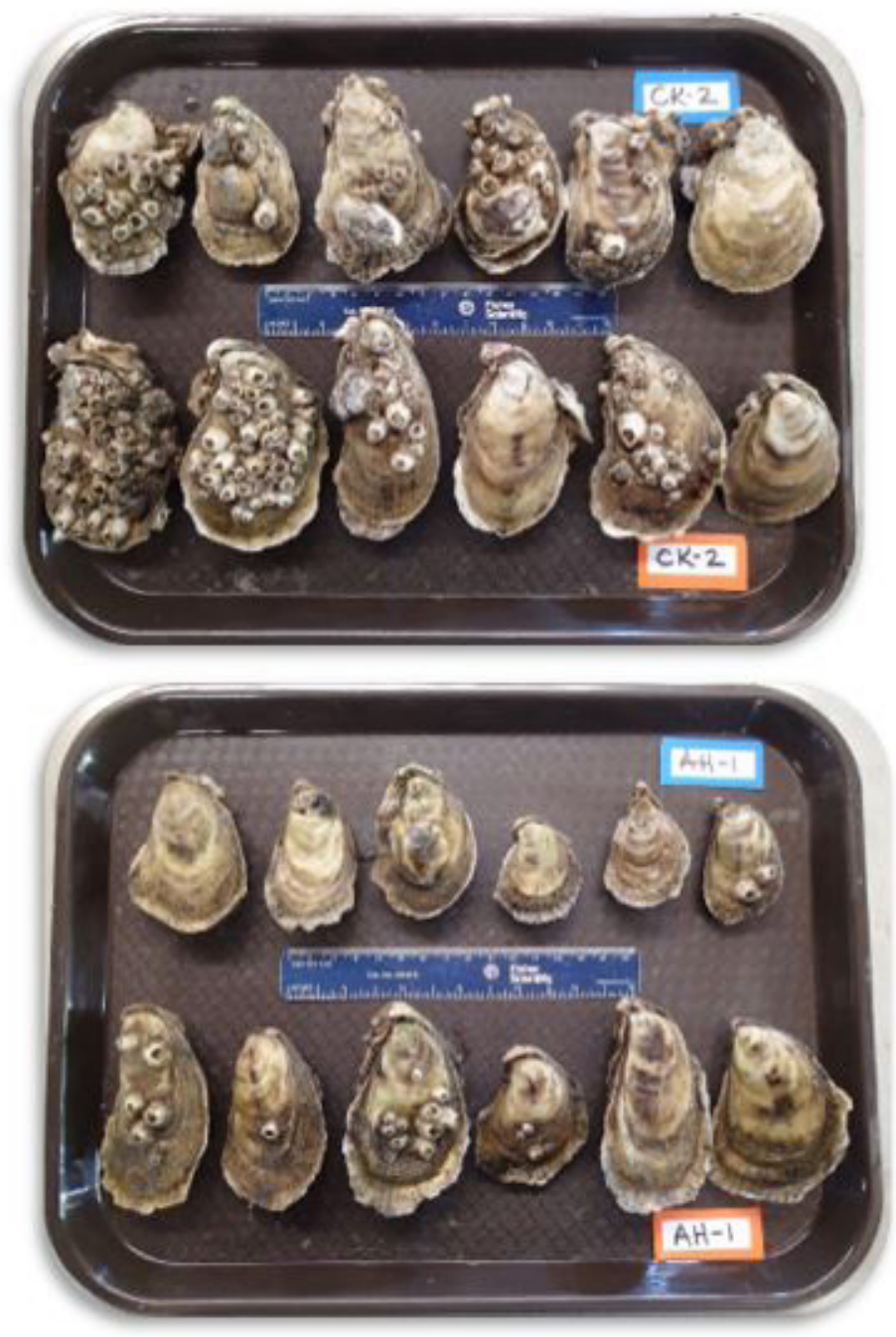

Figure 1. Diploid and triploid oysters harvested after eight months of growout in off-bottom gear at commercial farms along the west coast of Florida ( $\mathrm{CK}=\mathrm{Cedar} \mathrm{Key}, \mathrm{OB}=\mathrm{Oyster} \mathrm{Bay}, \mathrm{AH}=$ Alligator Harbor). Oysters on the top of each tray are diploids (blue tags) while oysters on the bottom of each tray are triploids (orange tags). 
other hand, triploid eastern oysters have shown resistance to the MSX disease (caused by Haplosporidium nelsoni) compared to diploids (Matthiessen \& Davis 1992). When exposure to the Roseovarius oyster disease (ROD, caused by Roseovarius crassostreae), triploid eastern oysters showed increased survival compared to diploids (Guo et al. 2008). For the Pacific oyster, triploids challenged to vibriosis did not show any advantage for susceptibility over diploids (DeDecker et al. 2011). Although disease resistance of triploids was not confirmed in these studies, it is worth noting that increased growth rates in triploid oysters could allow them to reach a "refuge" size to be harvested sooner, and thus reduce the risk of vulnerability to pathogens during the culture cycle.

\section{Ploidy Determination}

Accurate ploidy determination is absolutely required for the application of triploid-tetraploid technology. Ploidy verification of broodstock before spawning can ensure that hatchery efforts are carried out as planned; ploidy confirmation of larvae at swimming stage can ensure early detection of possible polyploid outcome; and ploidy validation of seed labeled as triploids before shipment can ensure that no mishandling occurred during the larval and seed rearing process. The methods for ploidy determination include the following:

\section{1) Counting of Chromosome Number}

This is a direct method for ploidy determination. Chromosomes are densely packaged chromatin (DNA and histone protein) within the nucleus of the cells and are visible with a light microscope, particularly during metaphase (a short period of the cell cycle). This method requires a tedious and time-consuming process that includes making cell suspensions, treating samples to assure cells arrest at the stage for visible chromosomes, making chromosome slides, staining chromosomes, and counting chromosomes. This method is usually used for ploidy determination at embryo stages or aneuploidy detection.

\section{2) Evaluation of Hemocyte Nucleus Diameters or Volume}

Blood cells (hemocytes) and nucleus dimensions in triploids are significantly bigger than those in diploids; therefore, these parameters can be used effectively for ploidy evaluation (Jayaprasad et al. 2011). The measurement of cell size (nuclear volume, cytoplasmic volume, and nucleus surface area) can be performed by microscopy after proper staining.

\section{3) Evaluation of DNA Amount by Flow Cytometry}

Flow cytometry is a technology that measures the characteristics of single cells in a fluid as it passes through a bright-beam laser. The cells can be labeled with specific fluorescent stains that can be excited to emit light at varying wavelengths as they pass through the laser. For ploidy determination, fluorescent stains for DNA amount (ratio to the chromosome numbers), including 4,6-diamidino2-phenylindole (DAPI) and propidium iodide (PI), can be used to stain the single cells (sperm, hemocytes, or cells isolated from gill or pooled larvae). The intensity of exit lights is proportional to the DNA amount and allows the different ploidy to be distinguished. Therefore, flow cytometry is a fast, easy, and accurate method for ploidy determination. For flow cytometry data collection, diploid oysters should be used as a reference because flow cytometry measures the relative DNA content (Allen 1983).

\section{4) Molecular Genetic Markers}

Polymorphic genetic markers, such as microsatellite markers, have been used for ploidy determination and parentage assignment in shellfish (Miller et al. 2016) because of their high polymorphism, multi-alleles, co-dominance, and reproducibility. The analysis can be achieved by using a simple multiplex polymerase chain reaction (PCR) containing specific primers of microsatellite markers.

\section{Conclusion}

Triploid oysters are now being sold as a commercial product in many countries, including the United States, Australia, France, Chile, China, and Korea, and have demonstrated improved performance compared to diploids. To further advance the marketability and production of triploid oysters, the establishment of tetraploid breeding stocks is the key for $100 \%$ triploid seed production. Overall, triploid-tetraploid technology is the most applied genetic manipulation to improve and sustain the global oyster aquaculture industry.

\section{Glossary}

Aneuploids: Organisms with a chromosome number other than an exact multiple of the haploid set, such as $2 \mathrm{n}-1$ (monosomy), $2 \mathrm{n}+1$ (trisomy), $2 \mathrm{n}+2$ (tetrasomy), and $2 \mathrm{n}+3$ (pentasomy).

Aneuploidy: describes the aneuploid condition. 
Chromosome: A threadlike structure of deoxyribonucleic acid (DNA) carrying genetic information in the form of genes in the nuclei of most living cells.

Euploids: Organisms with a chromosome number that is an exact multiple of a haploid chromosome set are called Euploids, such as diploids (2n) with two sets of chromosomes (most natural Animalia species are diploids), triploids (3n) with three sets of chromosomes, and tetraploids $(4 \mathrm{n})$ with four sets of chromosomes.

Gamete: Reproductive cells with a haploid number of chromosomes, including eggs, sperm, and spores. In sexual reproduction, gametes from males and females form diploid zygotes through fertilization.

Haploid: Possessing a single set of unpaired chromosomes $(1 \mathrm{~N})$, such as eggs and sperm.

Meiosis: The cell division process to produce gamete cells (eggs and sperm) or spores that involves one replication of chromosomes and two nuclear divisions to produce four haploid cells (gametes or plant spores). The first cell division is called Meiosis I, and the second cell division is called Meiosis II. The first stage of each cell division is called Prophase.

Ploidy: The number of sets of chromosomes in a cell, or in the cells of an organism. Usually, most animals possess two sets of chromosomes in a cell, which are called diploid.

Polar body: The cells produced at either the first cell division (polar body I) or the second cell division (polar body II) in the meiosis process in females. They usually contain almost no cytoplasm due to the unequal cell division.

Sexual maturation: Age or stage when an organism can reproduce.

Somatic: Not reproductive. A somatic cell is any cell of a living organism other than the reproductive cells. Somatic growth is the growth of nonreproductive tissues.

\section{References}

Akashige, S., and T. Fushimi. 1992. "Growth, survival, and glycogen content of triploid Pacific oyster Crassostrea gigas in the waters of Hiroshima, Japan." Nippon Suisan Gakkaishi 58: 1063-71.

Allen, S. K. 1983. "Flow cytometry-Assaying experimental polyploid fish and shellfish." Aquaculture 33: 317-28.
Allen, S. K., S. L. Downing, J. Chaiton, and J. H. Beattie. 1986. "Chemically and pressure-induced triploidy in the Pacific oyster Crassostrea gigas.” Aquaculture 57: 359-60.

Allen, S. K., A. J. Erskine, E. J. Walker, \& G. A. DeBrosse. 2005. "Production of tetraploid suminoe oysters, Crassostrea ariakensis." Aquaculture 247: 3.

Allen, S. K., Jr., S. L. Downing, \& K. K. Chew. 1989. Hatchery Manual for Producing Triploid Oysters. University of Washing Press, Seattle, Washington.

Barber, B. J., and R. Mann. 1991. "Sterile triploid Crassostrea virginica (Gmelin, 1791) grow faster than diploids but are equally susceptible to Perkinsus marinus." Journal of Shellfish Research 10: 445-50.

Brake, J., J. Davidson, and J. Davis. 2004. "Field observations on growth, gametogenesis, and sex ratio of triploid and diploid Mytilus edulis." Aquaculture 236: 179-91.

De Decker, S., J. Normand, D. Saulnier, F. Pernet, S. Castagnet, and P. Boudry. 2011. "Responses of diploid and triploid Pacific oysters Crassostrea gigas to Vibrio infection in relation to their reproductive status." Journal of Invertebrate Pathology 106: 179-91.

Degremont, L., C. Garcia, A. Frank-Lawale, and S. K. Allen. 2012. "Triploid oysters in the Chesapeake Bay: Comparison of diploid and triploid Crassostrea virginica." Journal of Shellfish Research 31: 21-31.

Degremont L., C. Ledu, E. Maurouard, M. Nourry, and A. Benabdelmouna. 2016. "Effect of ploidy on the mortality of Crassostrea gigas spat caused by OsHV-1 in France using unselected and selected OsHV-1 resistant oysters." Aquaculture Research 47: 777-86.

Downing, S. L., and S. K. Allen. 1987. "Induced triploidy in the Pacific oyster, Crassostrea gigas-Optimal treatments with cytochalasin B depend on temperature." Aquaculture 61: 1-15.

Eudeline, B., S. K. Allen, and X. M. Guo. 2000/ "Optimization of tetraploid induction in Pacific oysters, Crassostrea gigas, using first polar body as a natural indicator." Aquaculture 187: 73-84.

FAO. 2016. The State of World Fisheries and Aquaculture 2016, contributing to food security and nutrition for all. p. 200, Rome. 
Galtsoff, P. S. 1964. The American oyster, Crassostrea virginica Gmelin, Fishery Bulletin Volume 64. United States Government Printing Office, Washington, D. C.

Garnier-Gere, P. H., Y. Naciri-Graven, S. Bougrier, A. Magoulas, M. Heral M, G. Kotoulas, A. Hawkins, and A. Gerard. 2002. "Influences of triploidy, parentage and genetic diversity on growth of the Pacific oyster Crassostrea gigas reared in contrasting natural environments." Molecular Ecology 11: 1499-514.

Gosling, E. 2003. Bivalve Mulluscs Biology, Ecology and Culture. Fishing News Books, Malden, MA.

Guo, X. 2004. "Oyster breeding and the use of biotechnology." Bulletin of the Aquaculture Association of Canada 104: 26-33.

Guo, X. 2012. "Production and breeding of tetraploid eastern oyster Crassostrea virginica." Journal of Shellfish Research 31: 292.

Guo, X., and S. K. Allen Jr. 1994. "Viable tetraploids in the Pacific oyster (Crassostrea gigas Thuneberg) produced by inhibiting polar body 1 in eggs from triploids." Molecular Marine Biology abd Biotechnology 3: 42-50.

Guo, X., W. K. Hershberger, K. Cooper, and K. K. Chew. 1992. "Genetic consequences of blocking polar body I with cytochalasin B in fertilized eggs of the Pacific oyster, Crassostrea gigas. 2. Segregation of chromosomes." Biological Bulletin 183: 387-93.

Guo, X., Y. Wang, G. A. Debrosse, D. Bushek, and S. E. Ford. 2008. "Building a superior oyster for aquaculture." Jersey Shoreline 25: 7-9.

Guo, X., Y. Wang, Z. Xu, and H. Yang. 2009. "Chromosome Set Manipulation in Shellfish.” In: New Technologies in Aquaculture: Improving Production Efficiency, Quality and Environmental Management (eds. by Burnell G \& Allen G), pp. 165-94. Woodhead Publishing Limited, Abington, Cambridge.

Guo, X. M., G. A. DeBrosse, and S. K. Allen. 1996. "Alltriploid Pacific oysters Crassostrea gigas Thunberg produced by mating tetraploids and diploids." Aquaculture 142: $149-61$.

Hand, R. E., and J. A. Nell. 1999. "Studies on triploid oysters in Australia - XII. Gonad discolouration and meat condition of diploid and triploid Sydney rock oysters Saccostrea commercialis in five estuaries in New South Wales, Australia." Aquaculture 171: 181-94.

Hand, R. E., J. A. Nell, and P. A. Thompson. 2004. "Studies on triploid oysters in Australia XIII: Performance of diploid and triploid Sydney rock oyster, Saccostrea glomerata (Gould, 1850), progeny from a third generation breeding line." Aquaculture 233: 93-107.

Harding, J. M. 2007. "Comparison of growth rates between diploid deby eastern oysters Crassostrea virginica, (Gmelin 1791), triploid eastern oysters, and triploid Suminoe oysters C. ariakensis (Fugita 1913)." Journal of Shellfish Research 26: 961-72.

Hawkins, A. J. S., A. J. Day, A. Gerard A, Y. Naciri, C. Ledu, B. L. Bayne, and M. Heral. 1994. "A genetic and metabolic basis for faster growth among triploids induced by blocking meiosis I but not meiosis II in the larviparous European flat oyster, Ostrea edulis L." Journal of Experimental Marine Biology and Ecology 184: 21-40.

Jayaprasad, P. P., T. C. Srijaya, D. Jose, A. Papini, A. Hassan, and A. K. Chatterji. 2011. "Identification of diploid and triploid red tilapia by using erythrocyte indices." Caryologia 64, 485-92.

Liang, Y., R. Wang, C. Tian, R. Yu, and X. Qu. 1994. “A preliminary study on the triploid oyster Crassostrea talienwanese." Journal of Fisheries of China 18: 237-40.

Maguire, G. B., N. C. Gardner, J. A. Nell, G. N. Kent, and A. S. Kent. 1995. "Studies on triploid oysters in Australia. 2. Growth, condition index gonad area, and glycogen content of triploid and diploid Pacific oysters, Crassostrea gigas, from oyster leases in Tasmania, Australia." Aquaculture 137: 357.

Mallia, J. V., P. Muthiah, and P. C. Thomas. 2006. Growth of triploid oyster, Crassostrea madrasensis (Preston)." Aquaculture Research 37: 718-24.

Matthiessen, G. C., and J. P. Davis. 1992. "Observations on growth rate and resistance to MSX Haplosporidium nelsoni among diploid and triploid Eastern oysters Crassostrea virginica (Gmelin, 1797) in New England." Journal of Shellfish Research 449-54.

Miller, P. A., N. G. Elliott, R. E. Vaillancourt, A. Koutoulis, and J. M. Henshall. 2016. "Assignment of parentage in triploid species using microsatellite markers with null 
alleles, an example from Pacific oysters Crassostrea gigas." Aquaculture Research 47: 1288-98.

Nell, J. A., E. Cox, I. R. Smith, and G. B. Maguire. 1994. "Studies on triploid oysters in Australia. 1. The farming potential of triploid Sydney rock oysters Saccostrea commercialis (Iredale and Roughley)." Aquaculture 126: 243-55.

Nell, J. A., and B. Perkins. 2005. "Studies on triploid oysters in Australia: Farming potential of all-triploid Pacific oysters, Crassostrea gigas Thunberg, in Port Stephens, New South Wales, Australia." Aquaculture Research 36: 530-6.

Peachey, B. L., and S. K. Allen. 2016. "Evaluation of cytochalasin B and 6-dimethylaminopurine for tetraploidy induction in the Eastern oyster, Crassostrea virginica." Aquaculture 450: 199-205.

Stanley, J. G., S. K. Allen, and H. Hidu. 1981. "Polyploidy induced in the American oyster Crassostrea virginica with cytochalasin B." Aquaculture 23: 1-10.

Stanley, J. G., H. Hidu, and S. K. Allen. 1984. "Growth of American oysters increased by polyploidy induced by blocking meiosis I but not meiosis II." Aquaculture 37: $147-55$.

Stone, B. W., N. H. Hadley, and P. R. Kingsley-Smith. 2013. "Evaluating the potential growth advantage of triploid eastern oysters Crassostrea virginica in South Carolina relative to commercially cultured diploid native stocks." Journal of Shellfish Research 32: 647-55.

Sturmer, L. N., C. Cyr, R. Markham, N. Brandimarte, and S. Laramore. 2018. "Application of triploidy to an emergent oyster culture industry on the Florida west coast: Results of grower trials." Program and Abstracts of the 110th annual meeting of the National Shellfisheries Association: 169.

Troup, A. J., S. C. Cairns, and R. D. Simpson. 2005. "Growth and mortality of sibling triploid and diploid Sydney rock oysters, Saccostrea glomerata (Gould), in the Camden Haven River." Aquaculture Research 36: 1093-103.

Villanueva-Fonseca, B. P., A. M. Gongora-Gomez, N. P. Munoz-Sevilla, A. L. Dominguez-Orozco, J. A. HernandezSepulveda, M. Garcia-Ulloa, and J. T. Ponce-Palafox. 2017. "Growth and economic performance of diploid and triploid Pacific oysters Crassostrea gigas cultivated in three lagoons of the Gulf of California." Latin American Journal of Aquatic Research 45: 466-80.
Wadsworth, P. 2018. Comparing triploid and diploid growth and mortality in farmed oysters, Crassostrea virginica, in the northern Gulf of Mexico. Masters thesis, Auburn University, https://etd.auburn.edu/handle/10415/6074. 87 pp.

Wang, Y., X. Guo, G. A. Debrosse, and S. E. Ford. 2005. "Growth in natural triploid eastern oyster produced by diploid $\times$ tetraploid crosses." Journal of Shellfish Research 24: 1274.

Wang, Z., X. Guo, S. Allen, and R. Wang. 2002. "Heterozygosity and body size in triploid Pacific oysters, Crassostrea gigas Thunberg, produced from meiosis II inhibition and tetraploids." Aquaculture 204: 337-48.

Yang, H., and X. Guo. 2017. "Triploid hard clams Mercenaria mercenaria produced by inhibiting polar body I or polar body II." Aquaculture Research. (in press).

Yang, H., H. Que, Y. He, and F. Zhang. 2000a. "Chromosome segregation in fertilized eggs from zhikong scallop Chlamys farreri (Jones \& Preston) following polar body 1 inhibition with cytochalasin B." Journal of Shellfish Research 19: 101-5.

Yang, H., L. N. Sturmer, and S. Baker. 2016. Molluscan shellfish aquaculture and production. FA191. Gainesville: University of Florida Institute of Food and Agricultural Sciences. p. 8. http://edis.ifas.ufl.edu/fa191

Yang, H., F. Zhang, and X. Guo. 2000b. “Triploid and tetraploid Zhikong scallop, Chlamys farreri Jones et Preston, produced by inhibiting polar body I." Marine Biotechnology 2: 466-75.

Zhang, Y., J. Li, Y. Qin, Y. Zhou, Y. Zhang, and Z. N. Yu. 2017. "A comparative study of the survival, growth and gonad development of the diploid and triploid Hong Kong oyster, Crassostrea hongkongensis (Lam \& Morton 2003)." Aquaculture Research 48: 2453-62. 
Table 1. Performance of triploid oysters measured as percent increase in whole body weight over diploids unless otherwise noted (updated from Guo et al. 2009).

\begin{tabular}{|c|c|c|c|c|c|}
\hline Species & Method ${ }^{1}$ & $\begin{array}{l}3 \mathbf{N} \\
(\%)\end{array}$ & $\begin{array}{l}\text { Increase } \\
(\%)\end{array}$ & $\begin{array}{l}\text { Age } \\
\text { (year) }\end{array}$ & Reference \\
\hline \multirow[t]{8}{*}{ Crassostrea virginica } & $\mathrm{CB}, 0.5 \mathrm{mg} / \mathrm{L}$ & $61-72$ & $12-41$ & 3 & (Stanley et al. 1984) \\
\hline & $\mathrm{CB}, 0.5 \mathrm{mg} / \mathrm{L}$ & 96 & 30 & 2 & (Barber \& Mann 1991) \\
\hline & $\begin{array}{l}\mathrm{CB}, 0.5 \mathrm{mg} / \mathrm{L} ; \\
2 \mathrm{n} \times 4 \mathrm{n}\end{array}$ & $72 ; 98$ & $-0.7 ; 34$ (tissue) & 2.2 & (Wang et al. 2005) \\
\hline & $2 n \times 4 n$ & 100 & $\begin{array}{l}\text { Reaching market } \\
\text { size } \\
3 \mathrm{n}, 1.2 \mathrm{yr} ; 2 \mathrm{n}, 1.5 \mathrm{yr}\end{array}$ & -- & (Harding 2007) \\
\hline & $2 n \times 4 n$ & 100 & $82-192$ & 1.3 & (Guo et al. 2008) \\
\hline & $2 n \times 4 n$ & 100 & 91-109 & 1.5 & Allen, personal comm. \\
\hline & $2 n \times 4 n$ & 100 & $88 \%$ & 2 & (Degremont et al. 2012) \\
\hline & $\begin{array}{l}2 \mathrm{n} \times 4 \mathrm{n} \\
\text { (South } \\
\text { Carolina) }\end{array}$ & 100 & $\begin{array}{l}\text { 5-9\% body length } \\
6-30 \% \text { (dry weight) }\end{array}$ & 0.67 & (Stone et al. 2013) \\
\hline \multirow[t]{8}{*}{ Crassostrea gigas } & $\mathrm{CB}, 1 \mathrm{mg} / \mathrm{L}$ & $71-96$ & 28 & 1.5 & (Allen et al. 1986) \\
\hline & CB or 6-DMAP & 86 & 40 & 0.8 & (Garnier-Gere et al. 2002) \\
\hline & $\mathrm{CB}, 0.5 \mathrm{mg} / \mathrm{L}$ & 76 & $20-23$ & $2.3-3.2$ & (Maguire et al. 1995) \\
\hline & $\mathrm{CB}, 1.0 \mathrm{mg} / \mathrm{L}$ & 84 & $80-150$ & $1.5-2$ & (Akashige \& Fushimi 1992) \\
\hline & $\begin{array}{l}\mathrm{CB}, 0.5 \mathrm{mg} / \mathrm{L} ; \\
4 \mathrm{n}\end{array}$ & $82-100$ & $14 ; 26$ & 1 & (Wang et al. 2002) \\
\hline & $2 n \times 4 n$ & 100 & $25-51$ & 0.8 & (Guo et al. 1996) \\
\hline & $2 n \times 4 n$ & 99-100 & 159 & 1 & (Nell \& Perkins 2005) \\
\hline & $\begin{array}{l}\text { Not available } \\
\text { (NA) }\end{array}$ & NA & No advantage & $\sim 1$ & (Villanueva-Fonseca et al. 2017) \\
\hline $\begin{array}{l}\text { Crassostrea } \\
\text { hongkongensis }\end{array}$ & $\mathrm{CB}, 0.5 \mathrm{mg} / \mathrm{L}$ & & $5.7-15.5$ & 1 & (Zhang et al. 2017) \\
\hline $\begin{array}{l}\text { Crassostrea } \\
\text { talienwhanensis }\end{array}$ & $\begin{array}{l}\text { Cold shock, } \\
2-8^{\circ} \mathrm{C}\end{array}$ & $43-70$ & 52 (length) & 1 & (Liang et al. 1994) \\
\hline Crassostrea madrasensis & $\begin{array}{l}\text { 6-DMAP, } 100 \\
\mu \mathrm{M}\end{array}$ & $\mathrm{n} / \mathrm{a}$ & $128-260$ & 1 & (Mallia et al. 2006) \\
\hline Ostrea edulis & $\mathrm{CB}, 1 \mathrm{mg} / \mathrm{L}$ & $\mathrm{n} / \mathrm{a}$ & 61 (PB1); -8 (PB2) & 1.25 & (Hawkins et al. 1994) \\
\hline \multirow[t]{4}{*}{ Saccostrea glomerata } & $\mathrm{CB}, 0.5 \mathrm{mg} / \mathrm{L}$ & 85 & 41 & 2.5 & (Nell et al. 1994) \\
\hline & $\mathrm{CB}, 1.25 \mathrm{mg} / \mathrm{L}$ & 73-93 & $36-57$ & 2 & (Hand \& Nell 1999) \\
\hline & $\mathrm{CB}, 1.0 \mathrm{mg} / \mathrm{L}$ & $75-79$ & 74 & 1.3 & (Hand et al. 2004) \\
\hline & $\mathrm{CB}, 1.25 \mathrm{mg} / \mathrm{L}$ & $\mathrm{n} / \mathrm{a}$ & 49 & 3.2 & (Troup et al. 2005) \\
\hline
\end{tabular}

